\title{
TREND-ANTICIPATING VERSUS TREND-FOLLOWING
}

\author{
Adrian ZOICAŞ-IENCIU, ${ }^{a, *}$, Fănuța POP \\ a),b) Babeş-Bolyai University, Faculty of Economics and Business Administration, \\ Cluj-Napoca, Romania
}

Please cite this article as:

Article History:

Zoicaş-Ienciu, A. and Pop, F., 2017. Trend-anticipating versus trend-following. Review of Economic Studies and Research Virgil Madgearu, 10(2), pp.211-220.

doi: 10.24193/RVM.2017.10.17.

Abstract: This paper evaluates the impact of trading timing on trend-following performance for equity market indices across: (1) an ideal framework where investors successfully anticipate one-day-ahead signals and (2) a realistic framework with delayed transaction prices and cautious investors. We show that trend-following profits reduce significantly under the realistic trading timing. This bias is persistent, holds when controlling for trading costs, interests, and risk, being more pronounced for the emerging markets. Indirectly, the finding suggests that trend-anticipating tends to outperform trend-following as a trading strategy. Key words: technical analysis; trading timing; moving averages JEL Classification: G11; G12; G14

(C) 2017 Alma Mater Publishing House. All rights reserved.

* Corresponding author. E-mail address: adrian_ienciu@yahoo.com. 


\section{References}

1. Bajgrowicz, P., and Scaillet, O., 2012. Technical trading revisited: False discoveries, persistence tests, and trading costs. Journal of Financial Economics, 106(3), pp.473-491.

2. Bessembinder, H. and Chan, K., 1998. Market efficiency and the returns to technical analysis. Financial Management, 27, pp.5-17.

3. Brock, W., Lakonishok, J. and LeBaron, B., 1992. Simple technical trading rules and the stochastic properties of stock returns. Journal of Finance, 47, pp.1731-1764.

4. Han, Y., Yang, K. and Zhou, G., 2013. A new anomaly: The cross-sectional profitability of technical analysis. Journal of Financial and Quantitative Analysis, 48(5), pp.1433-1466.

5. Marshall, B.R., Cahan, R.H. and Cahan, J.M., 2008. Does intraday technical analysis in the U.S. equity market have value? Journal of Empirical Finance, 15(2), pp.199-210.

6. Ready, J.M., 2002. Profits from technical trading rules. Financial Management, 31(3), pp.43-61.

7. Shynkevich, A., 2017. Two tales of return predictability: The case of Asia-Pacific equity markets. Journal of Forecasting, 36(3), pp.257-272.

8. Sullivan, R., Timmermann, A. and White, H., 1999. Data-snooping, technical trading rule performance, and the bootstrap. Journal of Finance, 54(5), pp.1647-1691. 